In cooperation with the Louisiana Department of Transportation and Development

\title{
Water Resources of Ascension Parish
}

\section{Introduction}

Ascension Parish, located along the banks of the Mississippi River in south-central Louisiana (fig. 1), contains fresh groundwater and surface-water resources. In 2005, about 202 million gallons per day (Mgal/d) were withdrawn from water sources in Ascension Parish (fig. 2). About 94 percent (190 Mgal/d) was withdrawn from surface water, and 6 percent $(12 \mathrm{Mgal} / \mathrm{d})$ was withdrawn from groundwater (table 1). Additional water is supplied to Ascension Parish for public-supply use from East Baton Rouge Parish. Withdrawals for industrial use accounted for 95 percent (192 Mgal/d) of the total water withdrawn (table 2). Withdrawals for other uses included public-supply (4 Mgal/d), rural-domestic (3 Mgal/d), and aquaculture (3 Mgal/d). Water withdrawals in the parish generally increased from 1960 to 1995 and decreased from 1995 to 2005 (fig. 2).
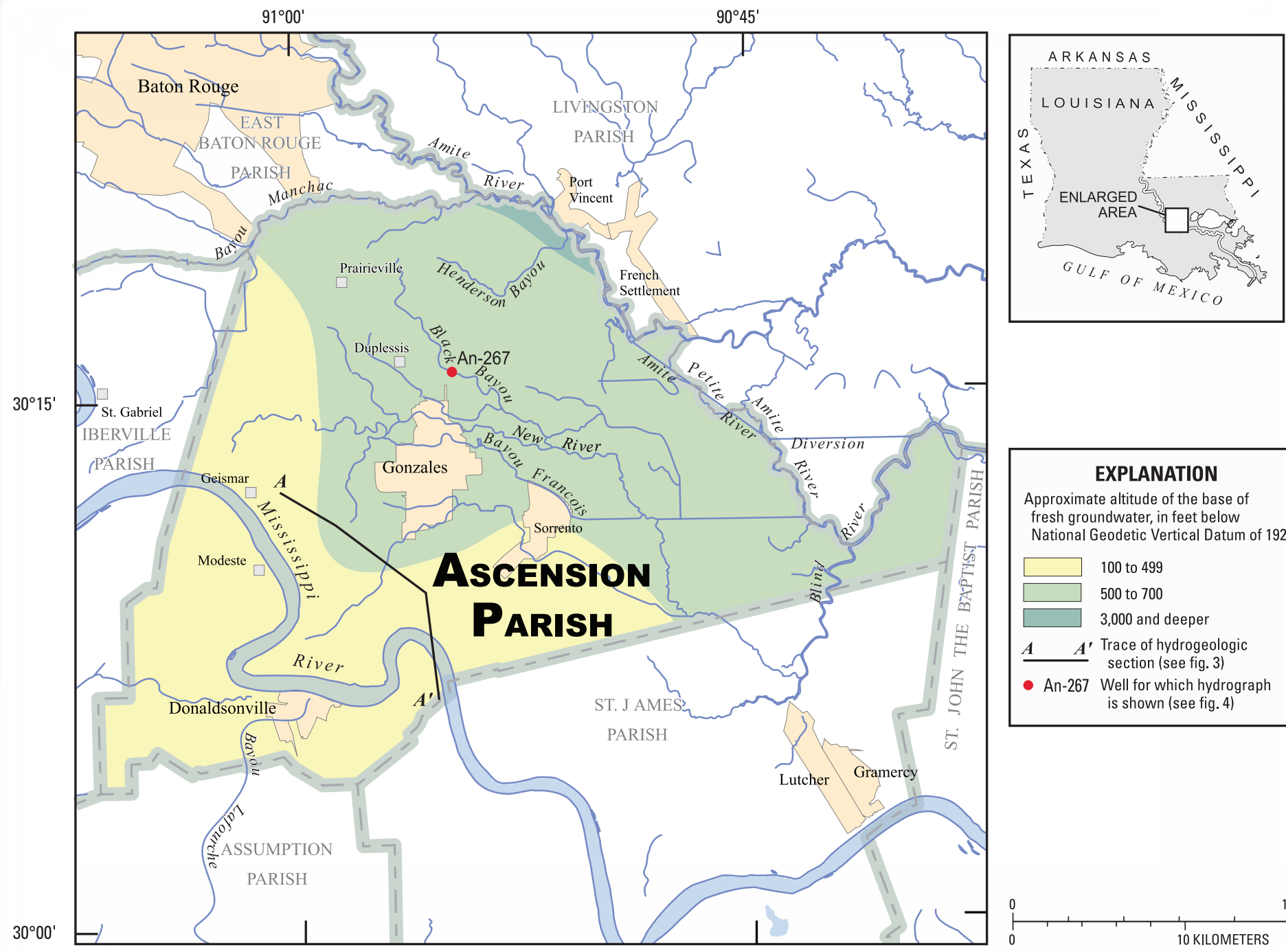

Base modified from Official Map of Louisiana, Louisiana Department of Transportation and Development, 1986

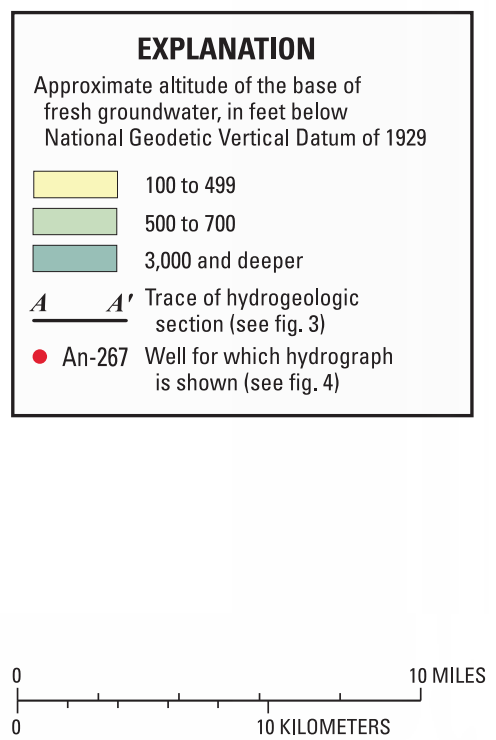

Figure 1. Location of study area, Ascension Parish, Louisiana. 
This fact sheet summarizes basic information on the water resources of Ascension Parish, La. Information on groundwater and surface-water availability, quality, development, use, and trends is based on previously published reports listed in the references section.

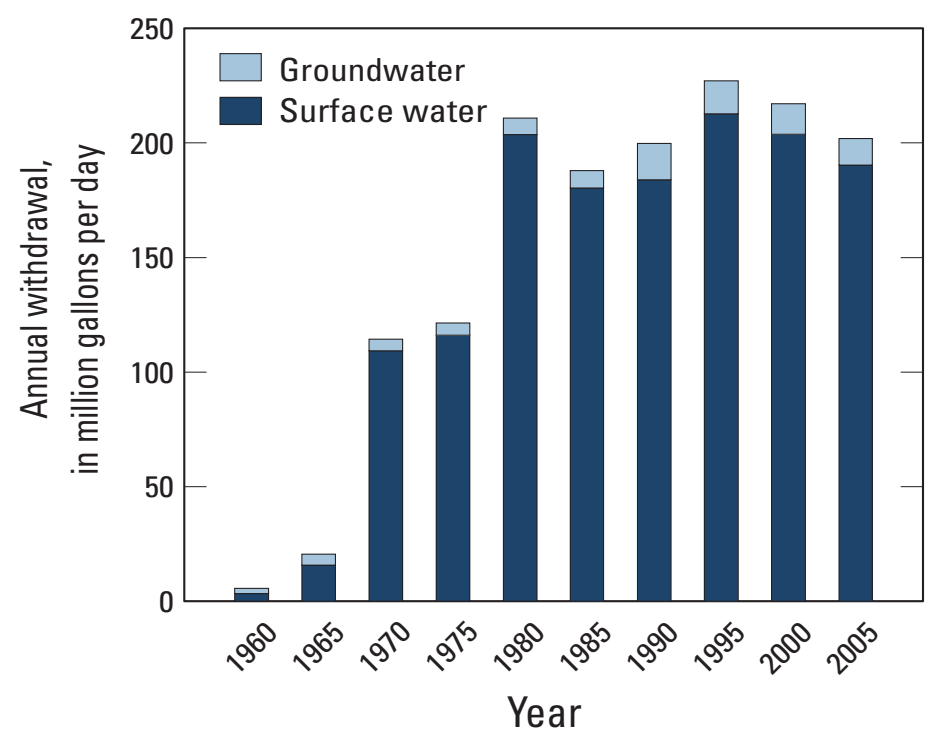

Figure 2. Water withdrawals in Ascension Parish, Louisiana, 1960-2005.

Table 1. Water withdrawals, in million gallons per day, by source in Ascension Parish, Louisiana, 2005 (Sargent, 2007).

\begin{tabular}{lcr}
\hline \multicolumn{1}{c}{$\begin{array}{c}\text { Aquifer, aquifer system, } \\
\text { or major water body }\end{array}$} & Groundwater & $\begin{array}{c}\text { Surface } \\
\text { water }\end{array}$ \\
\hline Mississippi River alluvial aquifer & 1.00 & \\
Chicot equivalent aquifer system & 10.65 & \\
Mississippi River & & 188.77 \\
Bayou Lafourche & & 1.53 \\
Other water bodies & & .03 \\
Total & 11.65 & 190.33 \\
\hline
\end{tabular}

Table 2. Water withdrawals, in million gallons per day, by category in Ascension Parish, Louisiana, 2005 (Sargent, 2007).

\begin{tabular}{lccc}
\hline & Groundwater & $\begin{array}{c}\text { Surface } \\
\text { water }\end{array}$ & Total \\
\hline Public supply & 2.64 & 1.53 & 4.17 \\
Industrial & 3.04 & 188.77 & 191.82 \\
Power generation & 0 & 0 & 0 \\
Rural domestic & 3.29 & 0 & 3.29 \\
Livestock & .11 & .03 & .14 \\
Rice irrigation & 0 & 0 & 0 \\
General irrigation & .04 & 0 & .04 \\
Aquaculture & 2.52 & 0 & 2.52 \\
\cline { 2 - 4 } Total & 11.65 & 190.33 & 201.98 \\
\hline
\end{tabular}

\section{Groundwater Resources}

The groundwater resources of Ascension Parish, from near surface to deepest, include the Mississippi River alluvial, Norco, and Gonzales-New Orleans aquifers (fig. 3 ). Fresh groundwater (water with a chloride concentration less than 250 milligrams per liter $[\mathrm{mg} / \mathrm{L}]$ ) is present from land surface to about $100 \mathrm{ft}$ below the National Geodetic Vertical Datum of 1929 (NGVD 29) in southwestern Ascension Parish (fig. 1) and to about $700 \mathrm{ft}$ below NGVD 29 in the northeastern part of the parish. Locally, near Port Vincent, fresh groundwater is present from near land surface to about $600 \mathrm{ft}$ below NGVD 29 and at depths of about 3,000 ft below NGVD 29, and intermediate sands may contain saltwater (water with a chloride concentration that exceeds $250 \mathrm{mg} / \mathrm{L}$ ).

Recharge to the aquifers is from rainfall, leakage from overlying aquifers, and seasonal input from rivers. Discharge from the aquifers is by natural flow into rivers, leakage into underlying aquifers, and withdrawal from wells.

Well-registration records from the Louisiana Department of Transportation and Development (DOTD) indicate that there are nearly 3,370 active wells screened in the aquifers in Ascension Parish, including about 2,915 domestic, 310 public-supply, 85 irrigation, and 60 industrial wells.

\section{Mississippi River Alluvial Aquifer}

The Mississippi River alluvial aquifer is located in western Ascension Parish and is present from land surface to depths of about 100 to $250 \mathrm{ft}$ below NGVD 29 . The Mississippi River alluvial aquifer consists of fine to coarse sand and a basal gravel, and it ranges in thickness from about 20 to $250 \mathrm{ft}$. The Mississippi River alluvial aquifer yields water that is usually very hard (greater than $180 \mathrm{mg} / \mathrm{L}$, as calcium carbonate $\left[\mathrm{CaCO}_{3}\right]$ ) and generally exceeds the U.S. Environmental Protection Agency's (EPA) 2006 Secondary Maximum Contaminant Levels (SMCLs) ${ }^{1}$ for drinking water for color, iron, and dissolved solids (table 3). About 115 wells are screened in the Mississippi River alluvial aquifer, and most are used for domestic (57), irrigation (34), industrial (16), or publicsupply (9) purposes. Reported well yields range from about 40 to 2,320 gallons per minute (gal/min). In 2005, withdrawals from the Mississippi River alluvial aquifer were about $1 \mathrm{Mgal} / \mathrm{d}$, and most were used for aquaculture $(0.7 \mathrm{Mgal} / \mathrm{d})$. Water levels in the Mississippi River alluvial aquifers are generally about $12 \mathrm{ft}$ above NGVD 29 and fluctuate 10 to $15 \mathrm{ft}$ seasonally, corresponding to water levels of the Mississippi River.

\footnotetext{
${ }^{1}$ The SMCLs are nonenforceable Federal guidelines regarding cosmetic effects (such as tooth or skin discoloration) or aesthetic effects (such as taste, odor, or color) of drinking water. At high concentrations or values, health implications as well as aesthetic degradation might exist. SMCLs were established as guidelines for the States by the U.S. Environmental Protection Agency (1992).
} 


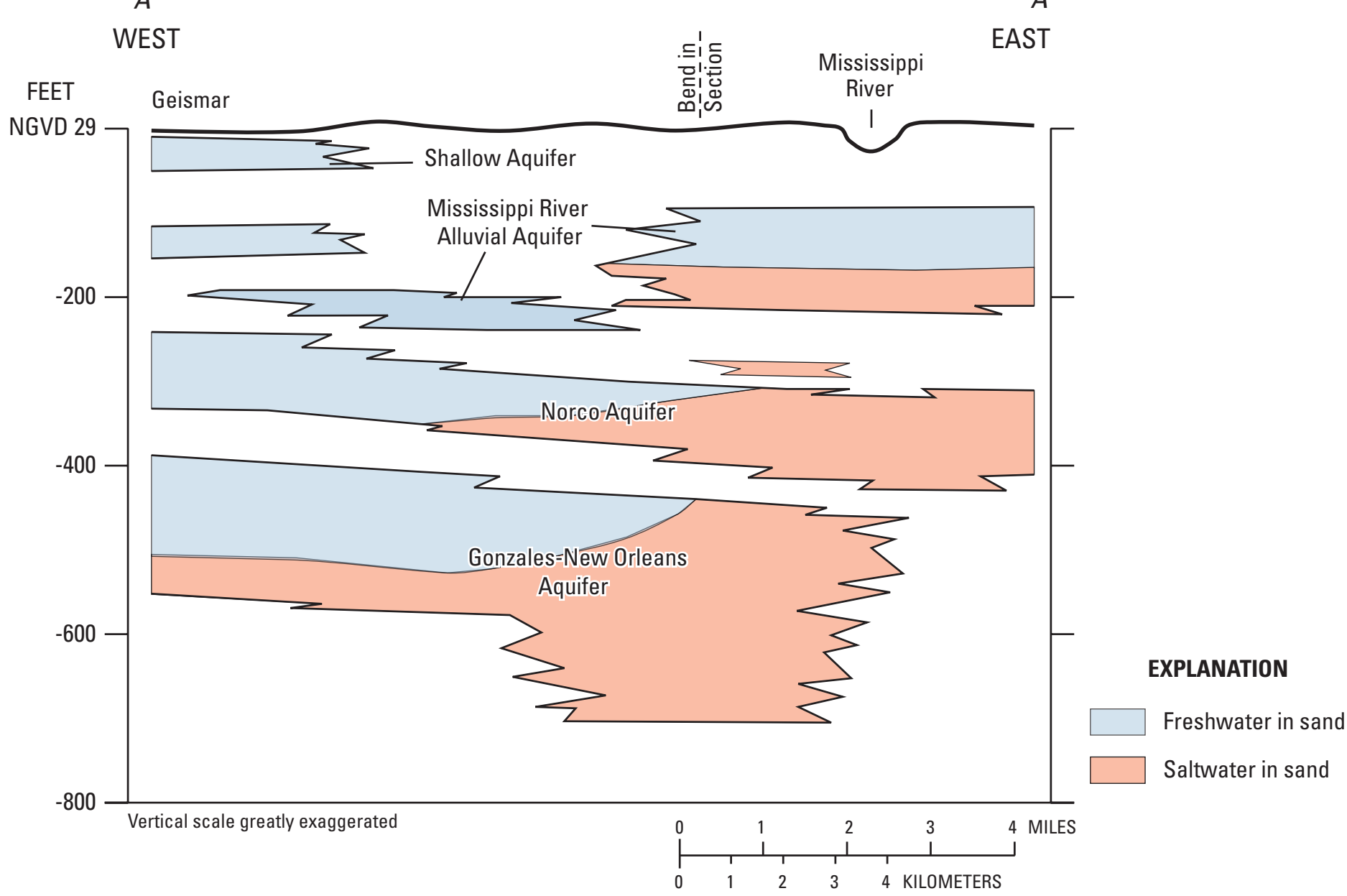

Figure 3. Generalized west-to-east hydrogeologic section through Ascension Parish, Louisiana (Tomaszewski, 2003). Trace of section shown on figure 1.

\section{Norco and Gonzales-New Orleans Aquifers}

The Norco aquifer is present throughout Ascension Parish, except the extreme northern part of the parish. It generally consists of 20 to $170 \mathrm{ft}$ of fine to coarse sand and some locally occurring small gravel. In Ascension Parish, the Norco aquifer contains freshwater in areas northeast of the Mississippi River. In much of the parish, the Norco aquifer yields water that is moderately hard $(61-120 \mathrm{mg} / \mathrm{L}$ as $\mathrm{CaCO}_{3}$ ) and can exceed the EPA's SMCLs for color and for iron and manganese concentrations (table 3). About 620 wells are screened in the Norco aquifer, and most are used for domestic (508), public-supply (59), irrigation (31), or industrial (22) purposes. Reported well yields range from about 25 to $430 \mathrm{gal} / \mathrm{min}$. In 2005, withdrawals from the Norco aquifer were about $3 \mathrm{Mgal} / \mathrm{d}$, and most were used for aquaculture (1.2 Mgal/d) and industrial (1.2 Mgal/d) purposes. Data from wells in the aquifer in neighboring St. James Parish indicate that water levels are generally about $5 \mathrm{ft}$ above NGVD 29 and fluctuate 4 to $10 \mathrm{ft}$ seasonally, corresponding to water levels in the Mississippi River.
The Gonzales-New Orleans aquifer is present throughout Ascension Parish. The aquifer consists of about 150 to $300 \mathrm{ft}$ of very fine to medium sand. The GonzalesNew Orleans aquifer contains freshwater in northern Ascension Parish and freshwater overlying saltwater in central parts of the parish. Where freshwater is present, the aquifer yields water that is soft (less than $60 \mathrm{mg} / \mathrm{L}$ as $\mathrm{CaCO}_{3}$ ) and generally exceeds the EPA's SMCL for manganese (table 3). About 2,580 wells are screened in the Gonzales-New Orleans aquifer, and most are used for domestic $(2,302)$ or public-supply $(231)$, industrial (20) or irrigation (20) purposes. Reported well yields range from about 30 to $200 \mathrm{gal} / \mathrm{min}$. In 2005, withdrawals from the Gonzales-New Orleans aquifer were about 4.6 Mgal/d, and most were for public-supply (2.6 Mgal/d) and industrial (1.8 Mgal/d) purposes. Water levels are generally about $1 \mathrm{ft}$ below NGVD 29 and fluctuate 4 to $8 \mathrm{ft}$ seasonally, as shown in the hydrograph of well An-267, located near Gonzales (fig. 4). 
Table 3. Summary of selected water-quality characteristics for freshwater in the Mississippi River alluvial, Norco, and Gonzales-New Orleans aquifers in Ascension Parish, Louisiana, 1933-2005 (U.S. Geological Survey, 2008b).

[Values are in milligrams per liter, except as noted. ${ }^{\circ} \mathrm{C}$, degrees Celsius; PCU, platinum cobalt units; $\mu \mathrm{S} / \mathrm{cm}$, microsiemens per centimeter; SU, standard units; $\mathrm{CaCO}_{3}$, calcium carbonate; $\mu \mathrm{g} / \mathrm{L}$, micrograms per liter; --, no value; NA, not applicable; SMCL, Secondary Maximum Contaminant Level established by the U.S. Environmental Protection Agency, 2006]

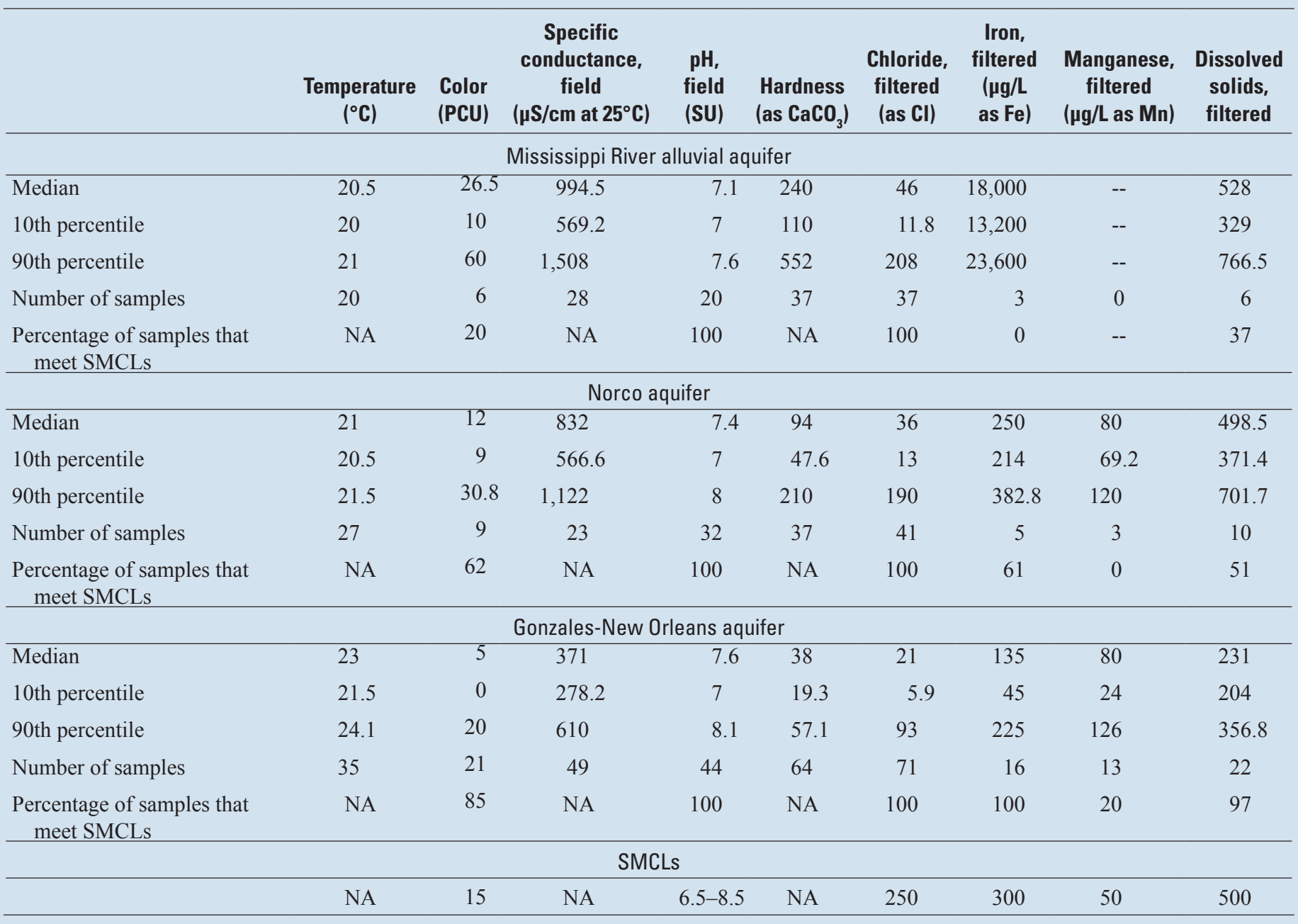

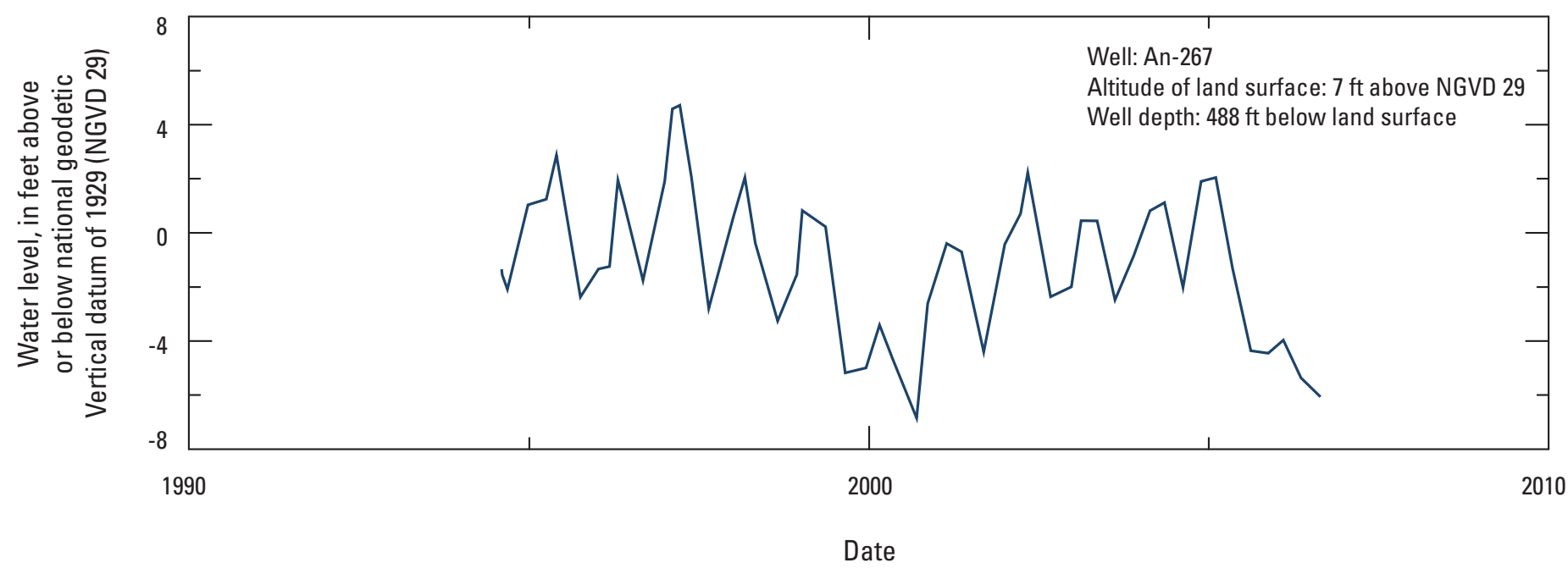

Figure 4. Water levels in well An-267 screened in the Gonzales-New Orleans aquifer in Ascension Parish, Louisiana (see fig. 1 for well location). 


\section{Surface-Water Resources}

The Mississippi River and Bayou Lafourche are primary sources of fresh surface water in Ascension Parish. Most of the water withdrawn from these sources is used for industrial and public-supply purposes. Other surface-water resources in the parish include the Amite River, Black Bayou, and Bayou Manchac.

About $189 \mathrm{Mgal} / \mathrm{d}$ of water were withdrawn from the Mississippi River in 2005 for industrial use in Ascension Parish. The average discharge of the Mississippi River at Tarbert Landing (USGS, 2008c; station 07295100), located about 100 mi upstream of Ascension Parish and downstream of the Old River Control Structure (in Concordia Parish), was about 460,000 cubic feet per second $\left(\mathrm{ft}^{3} / \mathrm{s}\right.$ ) (about 297,000 Mgal/d) for the period 1928-76. Water samples analyzed during the period 1975-2008 indicate that water in the Mississippi River at Baton Rouge is generally hard $\left(121-180 \mathrm{mg} / \mathrm{L}\right.$ as $\left.\mathrm{CaCO}_{3}\right) ; \mathrm{pH}$ and chloride and sulfate concentrations do not exceed the EPA's SMCLs (table 4).

About $1.5 \mathrm{Mgal} / \mathrm{d}$ of water were withdrawn from Bayou Lafourche for public supply (B.P. Sargent, U.S. Geological Survey, written commun., 2007). Bayou
Lafourche originates from water pumped from the Mississippi River at Donaldsonville and flows through southwestern Ascension Parish into Assumption Parish. The average discharge for Bayou Lafourche at Donaldsonville was about $245 \mathrm{ft}^{3} / \mathrm{s}(158 \mathrm{Mgal} / \mathrm{d})$ during the period 1961-85.

No water was withdrawn from the Amite River in 2005; however, the average discharge for the Amite River at Port Vincent was about 2,650 $\mathrm{ft}^{3} / \mathrm{s}(1,710 \mathrm{Mgal} / \mathrm{d})$ during the period 1988-2006.

\section{Selected References}

Cardwell, G.T., and Rollo, J.R., 1960, Interim report on groundwater conditions between Baton Rouge and New Orleans, Louisiana: Department of Conservation, Louisiana Geological Survey, and Louisiana Department of Public Works Water Resources Pamphlet no. 9, 44 p.

Dial, D.C., and Kilburn, Chabot, 1980, Ground-water resources of the Gramercy area, Louisiana: Louisiana Department of Transportation and Development, Office of Public Works Water Resources Technical Report no. 24, 39 p.

Table 4. Summary of selected water-quality characteristics for the Mississippi River and Bayou Lafourche in Ascension Parish, Louisiana, 1957-2008 (U.S. Geological Survey, 2008b).

[Values are in milligrams per liter, except as noted. ${ }^{\circ} \mathrm{C}$, degrees Celsius; $\mu \mathrm{S} / \mathrm{cm}$, microsiemens per centimeter; $\mathrm{SU}$, standard units; $\mu \mathrm{g} / \mathrm{L}$, micrograms per liter; $\mathrm{CaCO}$, calcium carbonate; NA, not applicable; SMCL, Secondary Maximum Contaminant Level established by the U.S. Environmental Protection Agency, 2006]

\begin{tabular}{|c|c|c|c|c|c|c|c|c|c|c|}
\hline & $\begin{array}{c}\text { Specific } \\
\text { conductance, } \\
\text { field } \\
\left(\mu \mathrm{S} / \mathrm{cm} \text { at } 25^{\circ} \mathrm{C}\right)\end{array}$ & $\begin{array}{l}\text { Oxygen, } \\
\text { dissolved }\end{array}$ & $\begin{array}{l}\text { pH, } \\
\text { field } \\
\text { (SU) }\end{array}$ & $\begin{array}{l}\text { Hardness } \\
\text { (as } \\
\mathrm{CaCO}_{3} \text { ) }\end{array}$ & $\begin{array}{l}\text { Calcium, } \\
\text { filtered } \\
\text { (as Ca) }\end{array}$ & $\begin{array}{c}\text { Magnesium, } \\
\text { filtered } \\
\text { (as Mg) }\end{array}$ & $\begin{array}{l}\text { Sodium, } \\
\text { filtered } \\
\text { (as Na) }\end{array}$ & $\begin{array}{c}\text { Chloride, } \\
\text { filtered } \\
\text { (as CI) }\end{array}$ & $\begin{array}{l}\text { Sulfate, } \\
\text { filtered } \\
\text { (as } \mathrm{SO}_{4} \text { ) }\end{array}$ & $\begin{array}{c}\text { Iron, } \\
\text { filtered } \\
\text { ( } \mu \mathrm{gg} / \mathrm{L} \text { as } \\
\text { Fe) }\end{array}$ \\
\hline \multicolumn{11}{|c|}{ Mississippi River at Baton Rouge ${ }^{1}$} \\
\hline Median & 397 & 8.3 & 7.7 & 150 & 39.6 & 12.6 & 17.4 & 23.2 & 40.4 & 8 \\
\hline 10th percentile & 316 & 6.3 & 7.2 & 120 & 32.5 & 9.2 & 12.3 & 15.8 & 28.3 & 4 \\
\hline 90th percentile & 471.7 & 11.7 & 8 & 180 & 45.2 & 15.3 & 23.8 & 29.4 & 53.3 & 32.1 \\
\hline Number of samples & 454 & 65 & 439 & 65 & 65 & 65 & 65 & 68 & 68 & 64 \\
\hline $\begin{array}{l}\text { Percentage of samples that } \\
\text { meet SMCLs }\end{array}$ & NA & NA & 99 & NA & NA & NA & NA & 100 & 100 & 100 \\
\hline \multicolumn{11}{|c|}{ Bayou Lafourche at Donaldsonville ${ }^{2}$} \\
\hline Median & 408 & 6.7 & 7.5 & 150 & 39.5 & 12 & 14 & 23 & 46 & 3 \\
\hline 10th percentile & 311.8 & 6 & 7.1 & 125 & 37 & 8.2 & 11 & 13.5 & 36.5 & 3 \\
\hline 90th percentile & 460.2 & 7.4 & 8 & 155 & 40 & 13 & 30 & 45.5 & 56 & 3 \\
\hline Number of samples & 5 & 2 & 6 & 6 & 6 & 6 & 5 & 6 & 6 & 1 \\
\hline $\begin{array}{l}\text { Percentage of samples that } \\
\text { meet SMCLs }\end{array}$ & NA & NA & 100 & NA & NA & NA & NA & 100 & 100 & 100 \\
\hline \multicolumn{11}{|c|}{ SMCLs } \\
\hline & NA & NA & $6.5-8.5$ & NA & NA & NA & NA & 250 & 250 & 300 \\
\hline
\end{tabular}


Long, R.A., 1965, Ground water in the Geismar-Gonzales area, Ascension Parish, Louisiana: Department of Conservation, Louisiana Geological Survey, and Louisiana Department of Public Works Water Resources Bulletin no. 7, 67 p.

Sargent, B.P., 2007, Water use in Louisiana, 2005: Louisiana Department of Transportation and Development Water Resources Special Report no. 16, 133 p.

Tomaszewski, D.J., 2003, Ground-water resources along the lower Mississippi River, southeastern Louisiana: Louisiana Department of Transportation and Development Water Resources Technical Report no. 69, 23 p.

U.S. Environmental Protection Agency, 1992, Secondary drinking water regulations - guidance for nuisance chemicals: U.S. Environmental Protection Agency publication EPA 810/K92-001, 4 p., accessed July 29, 2009, at http://www.epa.gov/ safewater/consumer/2ndstandards.html.

U.S. Environmental Protection Agency, 2006, 2006 Edition of the drinking water standards and health advisories: Washington D.C., U.S. Environmental Protection Agency, Office of Water, $12 \mathrm{p}$.

U.S. Geological Survey, 2008a, Ground-water levels for Louisiana: U.S. Geological Survey digital dataset, accessed May 22, 2008, at http://nwis.waterdata.usgs.gov/la/nwis/gwlevels.

U.S. Geological Survey, 2008b, Water-quality samples for Louisiana: U.S. Geological Survey digital dataset, accessed May 22, 2008, at http://nwis.waterdata.usgs.gov/la/nwis/ qwdata.

U.S. Geological Survey, 2008c, StreamStats: U.S. Geological Survey digital dataset, accessed September 16, 2011, at http://water.usgs.gov/osw/streamstats/index.html.

Wells, F.C., 1980, Hydrology and water quality of the lower Mississippi River: Louisiana Department of Transportation and Development, Office of Public Works Water Resources Technical Report no. 21, 83 p.

\section{By Jason M. Griffith and Robert B. Fendick}

\section{For additional information, contact:}

Director, USGS Louisiana Water Science Center 3535 S. Sherwood Forest Blvd., Suite 120

Baton Rouge, LA 70816

E-mail: dc_la@usgs.gov

Fax: (225) 298-5490

Telephone: (225) 298-5481

Home Page: http://la.water.usgs.gov
This fact sheet was published by the U.S. Geological Survey, in cooperation with the Louisiana Department of Transportation and Development (DOTD). Thanks are given to Zahir "Bo" Bolourchi, Director, Water Resources Programs, Louisiana Department of Transportation and Development, who contributed to the content and design of the fact sheet. 